EVALUASI, 3(2), September 2019, ISSN 2580-3387 (print) |

ISSN 2615-2886 (online)

Homepage : http://e-journal.staima-alhikam.ac.id/index.php/evaluasi

DOI $\quad:$ http://doi.org/10.32478/evaluasi.v3i2.251

Article type : Original Research Article

\title{
SERVANT LEADERSHIP DALAM IMPLEMENTASI NILAI-NILAI TRILOGI DAN PANCA KESADARAN SANTRI
}

\author{
Saifur Rizal \\ Program Pascasarjana \\ Universitas Nurul Jadid (UNUJA) Paiton Probolinggo \\ Jawa Timur
}

\begin{abstract}
The number of theories and models of leadership is a positive response from experts and scientists of various countries as a form of attention to the development and demands of the times. Likewise in the world of education, many leadership theories require educational institutions to be able to make changes in the framework of developing education towards progress in achieving a goal. Servant leadership is one of them, this leadership concept was taught and applied by Prophet Muhammad 14 centuries ago and was reiterated by Greenleaf several years ago. Servant leadership of a leadership theory that is widely applied in the world of Islamic education, especially Islamic boarding schools as the oldest Islamic educational institution in Indonesia. Including Nurul Jadid Islamic Boarding School in implementing trilogy values and the five santri awareness that are carried out continuously. In the process of implementing trilogy values and awareness of all santri in various management activities it is the main role in running a system. Servant leadership is a milestone in the success of the planting of these values to be able to be imbued by every santri to plunge into society.
\end{abstract}

Kata Kunci: Servant Leadership;trilogy; the five consciousness of santri

\footnotetext{
Abstrak

Banyaknya teori dan model kepemimpinan merupakan respon positif dari para pakar dan ilmuan berbagai negara sebagai bentuk perhatian terhadap perkembangan dan tuntutan zaman. Begitu pula dalam dunia pendidikan,

162 Email address: saifurrizal61@gmail.com

EVALUASI: Jurnal Manajemen Pendidikan is licensed under

The CC BY License (https://creativecommons.org/licenses/by-sa/4.0/)
} 
banyaknya teori kepemimpinan menuntut lembaga pendidikan untuk bisa melakukan perubahan dalam rangka pengembangan pendidikan ke arah kemajuan dalam mencapai sebuah tujuan. Kepemimpinan pelayan atau servant lesdership salah satunya, konsep kepemimpinan ini diajarkan dan diaplikasikan oleh Nabi Muhammad 14 abad tahun yang lalu dan dikemukakan kembali oleh greenleaf beberapa tahun yang lalu. Servant leadership sebuah teori kepemimpinan yang banyak diaplikasikan dalam dunia pendidikan Islam, terutama pondok pesantren sebagai lembaga pendidikan Islam tertua di Indonesia. Termasuk Pondok Pesantren Nurul Jadid dalam mengimplementasikan nilai-nilai trilogi dan panca kesadaran santri yang dilakukan secara berkesinambungan. Dalam proses implementasi nilai-nilai trilogi dan panca kesadaran kepada semua santri diberbagai aktifitas penguruslah yang menjadi pmeran utamanya dalam menjalankan sebuah sistem. Servant leadership menjadi tonggak dalam kemberhasilan penanaman nilai-nilai tersebut aagar mampu dijiwai oleh setiap santri hingga terjun ke masyarakat.

Kata Kunci: Servant Leadership;trilogi;panca kesadaran santri.

\section{PENDAHULUAN}

Kepemimpinan atau leadership telah menjadi kajian para ahli dan praktisi dari masa ke masa dan selalu menjadi sesuatu yang menarik untuk dikaji karena teori dan pendekatannya terus mengalami perkembangan dan berevolusi. Mulai dari yang mendasarkan pada karakter bawaan sejak lahir, kemudian berkembang menjadi gaya-gaya kepemimpinan, terus berkembang lagi menjadi tipe kepemimpinan yang sesuai dengan situasi-situasi tertentu, hingga sampai pada model kepemimpinan kontemporer yang menyesuaikan terhadap lingkungan yang dilihat dari bagaimana seorang leader atau pemimpin berinteraksi dengan orang lain atau bawahan sehingga mampu membawa pengikutnya menghadapi perubahan-perubahan dan tantangan-tantangan demi tercapainya sebuah tujuan.

Kepemimpinan merupakan konsep yang sangat penting, karena kepemimpinan dapat dapat menentukan kelangsungan suatu organisasi bahkan bisa menjadi peran kunci dalam menentukan maju mundurnya sebuah organisasi ${ }^{1}$. Selain itu para ulama Islam juga memberika perhatian

\footnotetext{
${ }^{1}$ James Tatilu, Victor P.K Lengkong, and Greis M. Sendow, 'Kepemimpinan Transaksional, Transformasional, Servant Leadership Pengaruhnya Terhadap Prestasi Pekerja Pada PT. Sinar Galeson Pratama Manado', Emba, 2.1 (2014), 295-304.
} 
yang serius dan khusus terhadap masalah kepemimpinan, karena mereka meyakini bahwa kepemimpinan adalah salah satu daya dukung agama ${ }^{2}$. Tidak menutup kemungkinan sebuah organisasi pasti akan berhadapan dengan kondisi lingkungan yang selalu mengalami perubahan secara cepat dan dinamis yang dipengaruhi oleh faktor internal maupun faktor eksternal. Demikian pula kepemimpinan dalam dunia pendidikan, khususnya kepemimpinan pendidikan pesantren sebagai kiblat pendidikan karakter. Maka dari itu, tentunya pimpinan pesantren membutuhkan kepemimpinan yang tepat agar mampu bertahan menghadapi perubahan dan tantangan yang terjadi, bahkan terus berkembang sesuai tuntutan zaman.

Pengasuh atau kepala pesantren sebagai pemimpin tertinggi sebuah pondok pesantren, pengurus adalah seorang pemimpin yang menjadi kepanjangan tangan atau berperan membantu pengasuh dengan tugas yang lebih spesifik pada pelayanan kepada santri serta memiliki kapasitas, kapabilitas dan kompetensi dalam segala bidang khususnya keagamaan. Sebagai pengurus pesantren memiliki tugas yang besar dan tanggungjawab yang sangat berat, karena tuntutan dari eksternal seperti wali santri, masyarakat umum, dan pengguna lulusan dan tuntutan internal seperti yayasan, dan dewan pengasuh serta daya saing ketika kembali ke tengahtengah masyarakat. Para pengurus harus menjaga kualitas dan kuantitas output atau lulusan pondok pesantren. Hal ini dilakukan untuk terus menjaga kontinuitas dan eksistensi pondok pesantren sebagai lembaga pendidikan Islam terbesar di Indonesia.

Berdasarkan uraian di atas, tentang urgensitas kepemimpinan pada lembaga pendidikan pesantren dan kompleksitas kesulitan yang dihadapi serta untuk memberikan sebuah jawaban dalam kebutuhan mayarakat, maka perlu kiranya mengetahui jenis kepemimpinan yang layak diimplementasikan oleh pengurus pesantren kepada santri di dalam lingkungan pondok pesantren secara umum dan Pondok Pesantren Nurul Jadid Paiton Probolinggo secara khusus. Demi tercapainya sebuah tujuan, visi dan misi pesantren yang secara mendasar tertuang di dalam trilogi dan panca kesadaran santri sebagai ciri-karakter seorang santri pondok pesantren Nurul Jadid.

Trilogi dan panca kesadaran santri yang disusun dan dibentuk oleh pendiri pondok pesantren nurul jadid harus dijiwai oleh setiap santri sebagai

2 Ila Kholilah, 'AN-NIDHOM (Jurnal Manajemen Pendidikan Islam) URGENSI KEPEMIMPINAN DALAM ISLAM Ila Kholilah’, 1.1, 117-30. 164 
bekal untuk mengabdi di tengah-tengah masyarakat. Untuk itu sejak awal santri sudah diberikan pemahaman dalam bentuk orientasi dan dilanjutkan penanaman isi kandungannya dengan proses pembiasaan yang diawasi dan dicontohkan langsung oleh pengurus Pondok Pesantren Nurul Jadid dengan pola kepemimpinan melayani (servant leadership) yang diformat dalam bentuk ke-wali asuhan. Jadi servant leadership adalah jenis kepemimpinanyag diterapkan pengurus Pondok Pesantren Nurul Jadidterhadap santri dalam penerapan nilai-nilai yang terkandung dalam trilogi dan panca kesadaran santri, karena pengurus beprinsip pada Sayyidul Qaum Khaddaamul Ummah (pemimpin dalam suatu kelompok adalah pelayan ummat).

\section{PEMBAHASAN}

\section{Kepemimpinan}

Konsep kepemimpinan merupakan komponen fundamental didalam menganalisis suatu proses dan dinamika di dalam sebuah organisasi. Menurut Maisah, kepemimpinan menjadi salah satu faktor penentu dari empat faktor yang mempengarugi kinerja seseorang yang meliputi aspek kualitas manajer dan team leader dalam memberikan dorongan, semangat, arahan dan dukungan kerja pada bawahannya ${ }^{3}$. Untuk itu daris dulu hingga sekarang banyak dilakukan kajian-kajian dan diskusi yang membahas definisi kepemimpinan yang terkadang justru membingungkan.

Ada banyak definisi tentang kepemimpinan, Menurut Crainer dalam mullins terdapat kurang lebih sebanyak 400 definisi tentang kepemimpina ${ }^{4}$. Dari sekian banyak definisi tentang kepemimpinan, ada yang menyebutkan bahwa pada intinya kepemimpinan merupakan suatu kegiatan untuk memengaruhi orang lain. Selaras dengan itu, Kepemimpinan atau yang dikenal dengan istilah leadership adalah seni untuk mempengaruhi individu atau kelompok dalam usaha kearah pencapaian tujuan pada situasi tertentu ${ }^{5}$. James A.F Stoner dan Charles Wankel mengatakan bahwa "nevertheless,

\footnotetext{
${ }^{3}$ Hasan Baharun, 'Manajemen Kinerja Jurnal I Lmu Tarbiyah " At - Tajdid", Vol . 5 No . 2 , Juli 2016', Jurnal I Lmu Tarbiyah “ At - Tajdid, 5.2 (2016), 243-62.

${ }^{4}$ Ilham Fahmi, 'Pengaruh Kepribadian Dan Persepsi Kerja Guru Terhadap Organizational Citizenship Behavior (Ocb) Guru Sma Negeri Se-Kabupaten Karawang', 1.1 (2017), 112-21.

5 Izani \& Yahya, 'Kepimpinan Servant Dan Pengaruhnya Terhadap Pengurusan Perubahan Di Sekolah', Jurnal Pendidikan Malaysia, 39.1 (2014), 19-26.
} 
EVALUASI, 3(2), September 2019, ISSN 2580-3387 (print) |

ISSN 2615-2886 (online)

http://doi.org/10.32478/evaluasi.v3i2.251

leadership abilities and skill in directing are important factors in managers effectiveness" (kepemimpinan adalah kemampuan dan keterampilan mengarahkan yang merupakan faktor penting dalam efektivitas manajer/pemimpin).

Secara mendasar kepemimpinan terbagi menjadi tiga ${ }^{7}$ yaitu: pertama,Self Leadership; memimpin diri sendiri dengan maksud supaya tidak gagal dalam kehidupan. Kedua, Organizational Leadership; memimpin organisasi dengan membawa organisasi dan institusi ke arah kemajuan. Ketiga, Team Leadership; memimpin orang lain dalam suatu kelompok. Kepemimpinan dalam organisasi memiliki peran yang sangat besar dalam membangun hubungan antar individu dan pembentuk nilai organisasi yang dijadikan sebagai pondasi dasar bagi pencapaian tujuan organisasi ${ }^{8}$.

Berdasarkan pada banyaknya kajian-kajian dalam sebuah literatur kepemimpinan, dari tahun ketahun dan masa kemasa minat dalam melakukan kajiankepemimpinanterus mengalami peningkatan yang cukup signifikan. Terbukti dengan berkembangnya gaya kepemimpinan seperti tradisional, otokrasi, dan hierarki pada awal abad ke-21 yang sedang dan masih secara perlahan-lahan menghasilkan sebuah gaya kepemimpinan terbarukan, yaitu gaya kepemimpinan yang mencoba untuk terus meningkatkan kualitas pertumbuhan personal dan profesionalitas personalia. Awal teori kepemimpinanhanya fokus pada kualitas yang membedakan antara pengikut dan pemimpin atau pimpinan, sementara ituteori-teori yang muncul berikutnya terus berbenah dengan melihat kondisi variabel-variabel lain, seperti faktorsituasional atau kondisi tertentu dan level keterampilan.

\section{KEPEMIMPINAN PELAYAN (SERVANT LEADERSHIP)}

Merenungkan kembali terkait makna dari leadership atau kepemimpinan, seringkali diartikan bahwa kepemimpinan adalah sebuah jabatan formal, yang menuntut untuk mendapat pengakuan, fasilitas dan pelayanan ekstra (extra service) dari konstituen yang seharusnya dilayani.

6 Abdul Aziz Wahab, 'Anatomi Organisasi Dan Kepemimpinan Pendidikan', in Bandung: Alfabeta, 201AD, p. 34.

7 Dadang Kadarusman, 'Natural Intellegence Leadership: Cara Pandang Baru Terhadap Kecerdasan Dan Karakter Kepemimpinan', in Jakarta: Raih Asa Sukse, 2012, p. 23.

${ }^{8}$ Hasan Baharun, 'Peningkatan Kompetensi Guru Melalui Sistem Kepemimpinan Kepala Madrasah', 6.1 (2017), 1-26.

166 
Dalam kenyataannya, sekarang banyak di antara pemimpin yang ketika dilantik mengatakan bahwa jabatan adalah sebuah tanggungjawab dan amanah yang sangat berat untuk dijalani, namun dalam kenyataannya sangat sedikit sekali bahkan bisa dikatakan hampir tidak ada pemimpin yang sungguh-sungguh menerapkan kepemimpinan dari hati. Padahal dalam kehidupan sehari-hari, baik dalam lingkungan keluarga, organisasi, pemerintahan dan semuanya termasuk dalam dunia pendidikan setiap orang pasti berharap dan mengidamkan pemimpin yang baik, pemimpin yang dapat memimpin kearah yang lebih baik dan mengayomi serta melayani bawahan dan pengikutnya dengan bijak dan berkeadilan tanpa membeda-bedakan.

Sejalan dengan apa yang diharapkan oleh banyak orang, kurang lebih 14 abad tahun yang lalu Nabi Muhammad SAW sebagai manusia yang tugaskan untuk menyampaikan risalah kenabiannya sudah memperkenalkan bahkan beliau sendiri sudah mengajarkan dengan cara mengamalkan konsep kepemimpinan pelayan atau servant leadership dalam segala aspek kehidupan sehari-hari. Hal ini terbukti dengan ditempatkannya Rasulullah Muhammad pada urutan pertama sebagai tokoh benpengaruh dunia dalam sebuah buku the 100 a ranking of the most influential person in history yang ditulis oleh Michael H. Hart.

Jika ditelaah kembali, kata tokoh "berpengaruh" merupakan nilai dasar dalam sebuah teori kepemimpinan. Dimana seorang pemimpin harus mampu mempengaruhi orang lain atau bawahannya untuk membawa perubahan kearah yang lebih baik sehingga tercapainya sebuah tujuan.

Sementara Robert K. Greenleaf memperkenalkan konsep servant leadership secara teoritis dalam tulisan essay pada tahun 1970 dengan judul The Servant as Leader yang diterbitkan secara pribadi dan dipublikasikan ke khalayak umum ${ }^{9}$. Dengan banyaknya respon positif, maka buku tersebut terus dilakukan cetak ulang dan didistribusikan ke seluruh negara serta sudah banyak yang menterjemahkan.

Menurut Greenleaf konsep servant leadership menekankan kepada peran seorang pemimpin sebagai seorang pelayan (steward). Dimana kata steward sendiri berasal dari kata 'oikonomia' yang berarti house manager. Sebagaimana seorang house manager diberi kepercayaan dengan sebuah tanggung jawab dalam mengurus urusan bisnis dalam rumah tangga. Sebagai

\footnotetext{
${ }^{9}$ Izani Bin Ibrahim and Dr. Yahya Bin Don, 'Servant Leadership and Effective Changes Management in Schools', International Journal of Scientific and Research Publication, 4.1 (2014), 1-8.
} 
ekspresi natural perilaku servanthood dalam diri seorang servant leader, berusaha untuk bertanggung jawab tidak terbatas hanya kepada orang yang dilayaninya saja tetapi juga untuk orang lain ${ }^{10}$.

Model servant leadership Greenleaf menempatkan posisi orang lain yang menjadi bawahan, termasuk santri dalam dunia pesantren, pelanggan dalam dunia jual-beli, karyawan dalam perusahaan atau dalam institusi lain, dan masyarakat sebagai prioritas paling utama. Jadi, karakteristik utama yang menjadi pembeda antara kepemimpinan pelayan dengan model kepemimpinan lainnya terletak pada keinginan untuk melayani dan terus melayani yang itu hadir jauh sebelum adanya keinginan untuk memimpin atau menjadi pemimpin. Selanjutnya mereka yang memiliki kualitas kepemimpinan akan menjadi pemimpin, sebab itulah cara yang paling efektisf untuk melayani ${ }^{11}$.

Sementara menurut Nouschel servant leadership adalah seorang pemimpin dengan pengikut yang ia bantu untuk berkembang dalam reputasi, kemampuan, atau dalam sejumlah hal memberi kontribusi untuk membangun mereka menjadi orang yang lebih berguna dan bahagia. Kepemimpinan pelayan merupakan suatu kepemimpinan yang berawal dari perasaan tulus yang timbul dari dalam hati yang berkehendak untuk melayani, yaitu untuk menjadi pihak pertama yang melayani ${ }^{12}$.

Menurut Page dan Wong, servant leadership diartikan sebagai seorang pemimpin yang mau melayani orang lain dengan mengupayakan pembangunan dan kesejahteraan untuk memenuhi tujuan bersama. Servant leader berperilaku etis, mendorong dan memberdayakan pengikutnya untuk tumbuh dan berhasil secara pribadi dan profesional ${ }^{13}$.

Servant leadership atau kepemimpinan pelayan menggambarkan pergeseran paradigma proses kepemimpinan yang memfokuskan pada memimpin (leading) menuju ke arah kepemimpinan yang memfokuskan pada

\footnotetext{
${ }^{10}$ Wa Ode Zusnita Muizu, 'Pengaruh Kepemimpinan Terhadap Kinerja Karyawan', Jurnal Pekbis, 6.1 (2014), 1-13.

${ }^{11}$ Dewi Urip Wahyuni, Budiman Christiananta, and Anis Eliyana, 'Influence of Organizational Commitment, Transactional Leadership, and Servant Leadership to the Work Motivation, Work Satisfaction and Work Performance of Teachers at Private Senior High Schools in Surabaya', Educational Research International, 3.2 (2014), 82-96.

${ }^{12}$ Ibrahim and Don.

${ }^{13}$ Robert F. Russell and A. Gregory Stone, 'A Review of the Servent Leadership Attributes', Leadership \& Organization Development Journal, 23/3 (2002), 145-57. 168
} 
EVALUASI, 3(2), September 2019, ISSN 2580-3387 (print) |

ISSN 2615-2886 (online)

http://doi.org/10.32478/evaluasi.v3i2.251

melayani (serving). Kepemimpinan servant adalah bentuk kepemimpinan yang berhubungan dengan kepemimpinan kharismatik dan transformasional, yang menekankan pada pemberdayaan para pengikut untuk mencapai tujuan organisasi ${ }^{14}$.

Untuk bisa mengimplementasikan konsep tersebut, dalam servant leadership ada beberapa faktor yang perlu diperhatikan. Hasil penelitian ${ }^{15}$ menghasilkan 5 faktor, yaitu:

1. Persuasive Mapping (pemetaan persuasif)

Para pemimpin mempengaruhi orang sekitarnya tidak selalu melalui jabatan formal, tetapi kebanyakan melalui kemampuan personal dalam persuasi. Persuasive mapping membantu orang lain untuk melihat gambaran besarnya dan mencari jalan untuk mencapai tujuan.

2. Wisdom (Kebijaksanaan)

Yaitukemampuan untuk melihat apa yang diinginkan dalam situasi sekarang dan memberi solusi bagaimana untuk mencapainya. Servant leader memiliki kebijaksanaan dan memberdayakannya dalam diri orangorang disekitarnya.

3. Altruistic Calling(Panggilan Altruistik)

Altruistik adalah tindakan suka rela untuk menolong orang lain tanpa mengharapkan imbalan dan tanpa pamrih. Servant leader menggambarkan pekerjaan yang ada sebagai pelayanan terhadap kelompok dan orang-orang yang dilayani, pelayanan itu sendiri sebuah penghargaan bagi seorang servant leader.

4. Emotional Healing (penyembuhan emosi)

Ketika seseorang merasakan kekecewaan dengan pekerjaan yang dilakukan, dapat mempengaruhi komitmen masa depan terhadap organisasi. Dengan adanya komitmen seorang servant leader dalam memfasilitasi penyembuhan secara emosional yang dibutuhkan untuk meningkatkan semangat bawahan dari rasa kekecewaan yang dialami, dapat bergerak maju dan berkembang bersama dalam mencapai tujuan organisasi.

5. Organizational stewardship(pengelolaan organisasi)

\footnotetext{
${ }^{14}$ Rais Hidayat, 'Perilaku Etis Dosen Dalam Persfektif Efikasi Diri, Kepemimpinan, Dan Komunikasi Interpersonal', 1.1 (2017), 37-44.

${ }^{15}$ John E. Barbuto and Daniel W. Wheeler, 'Scale Development and Construct Clarification of Servant Leadership', Group and Organization Management, 31.3 (2006), 300-326.
} 
EVALUASI, 3(2), September 2019, ISSN 2580-3387 (print)|

ISSN 2615-2886 (online)

http://doi.org/10.32478/evaluasi.v3i2.251

Servant leader sebagai pengurus organisasi harus berpikiran jangka panjang dan perencanaan menggambarkan sejauh mana pemimpin menyiapkan organisasi untuk membuat kontribusi positif terhadap lingkungannya seperti melalui progam pengabdian masyarakat dan pengembangan komunitas serta mendorong pendidikan tinggi.

Berdasarkan uraian diatas, prinsip kepemimpinan servant leadership yang dikemukakan bahwa, servant leadership mendasarkan pada perilaku pemimpin dalam memengaruhi dan menggerakkan bawahan dalam mencapai tujuan organisasi berdasarkan pada tanggung jawab dengan memberikan pelayanan yang baik kepada bawahan dan meletakkan kepentingan bawahan di atas kepentingan pribadi pemimpin.

\section{TRILOGI DAN PANCA KESADARAN SANTRI}

Trilogi santri adalah standart kompetensi dasar yang harus dikuasai oleh setiap santri Pondok Pesantren Nurul Jadid. Sebagai kriteria minimal, santri wajib memahami dan mengamalkanya karena ini menjadi tolak ukur sebuah kesantrian. Secara etimologi, tri artinya tiga sedangkan logi berarti studi atau ilmu. Sementara santri sendiri di dalam wikipedia didefinisikan sebagai sebuah sebutan bagi seseorang yang mengikuti pendidikan agama Islam di pesantren, biasanya menetap di tempat tersebut sampai pendidikannya selesai. Jadi trilogi santri merupakan tiga bidang ilmu amaliah yang disusun oleh pendiri Pondok Pesantren Nurul Jadid untuk dijadikan pijakan dasar bagi santri terutama dalam ibadah, baik ibadah yang sifatnya mahdlah dan ghairu mahdlah maupun ibadah sosial kemasyarakatan. Trilogi santri pada dasarnya adalah komponen utama dari kesadaran beragama yang terdapat dalam panca kesadaran santri yang terdiri dari:

1. Memperhatikan kewajiban fardlu 'ain (ألإهتما م با الفروض العينية)

2. Mawas diri dengan meninggalkan dosa-dosa besar (ألإهتما م بتركالكبائر)

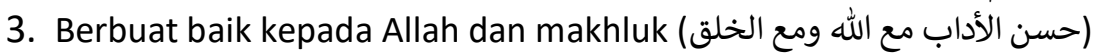

Sementara panca kesadaran santri adalah roh yang menjadi cirikarakter santri Pondok Pesantren Nurul Jadid. Dalam panca kesadaran santri terkandung nilai-nilai kesadaran yang bersifat universal dan komprehensif 
EVALUASI, 3(2), September 2019, ISSN 2580-3387 (print) |

ISSN 2615-2886 (online)

http://doi.org/10.32478/evaluasi.v3i2.251

sebagai bekal untuk perjuangan dan pengabdian di tengah-tengah kehidupan masyarakat.

Secara umum pesantren seolah-olah digambarkan sebagai kawah chandradimuka yang tak pernah kering memasok generasi muda yang ikhlas, berakhlak mulia, mandiri, agamis, nasionalis, patriotik, dan bertanggungjawab terhadap masnyarakat. Dengan berbekal kepercayaan masyarakat yang tinggi kepada pesantren, maka menuntut pesantren untuk selalu mengejawantahkan tiga fungsi yang melekat padanya. Tiga fungsi tersebut adalah; Pertama, sebagai media pengkaderan bagi pemikir-pemikir agama (centre of exellence). Kedua, sebagai lembaga yang mencetak sumber daya manusia (SDM). Dan ketiga, sebagai lembaga yang melakukan pemberdayaan masyarakat. Selain itu pesantren juga dipahami sebagai bagian yang terlibat aktif dalam proses perubahan sosial di tengah perubahan yang terjadi di Indonesia.

Pondok Pesantren Nurul Jadid sendiri dalam mengimplementasikan beberapa fungsi tersebut, menitikberatkan pada adanya panca kesadaran santri (al-wa'iyyat al-khamsah). Panca kesadaran ini meliputi kesadaran beragama, berilmu, bermasyarakat, berbangsa dan bernegara serta kesadaran berorganisasi.

1. Kesadaran beragama (الوعي الدينى)

Bagi santri Nurul Jadid kesadaran beragama merupakan titik awal yang harus terpatri dalam dirinya. Kesadaran beragama haruslah dilandasi dengan adanya wawasan keagamaan yang luas, tanggungjawab keagamaan yang tinggi dan penghayatan keagamaan yang mendalam. Apalagi dalam tradisi keilmuan Islam sendiri, antara ilmu dan amal haruslah berjalan beriringan.

Kesadaran beragama ini mencakup tiga aspek, yaituaqidah, ibadah, dan akhlak. Aqidah merupakan kualitas dasar yang harus dimiliki oleh setiap santri pondok pesantren nurul jadid. Yang dimaksud aspek aqidah adalah keyakinan yang mantap bahwa Allah SWT. itu maha esa dan hanya dia yang berhak disembah, dan Rasulullah Muhammad adalah nabi terakhir; segala berita yang dibawa oleh beliau harus dipercaya, baik berupa al-Qur'an maupun Sunnah atau Hadits nabi. Substansi aqidah tersimpul dalam dua kalimat syahadat, yaitu kesadaran yang utuh untuk bersaksi bahwa mereka bertuhankan Allah dan pengakuan bahwa 
Muhammad adalah utusan Allah. Dua kalimat syahadat ini harus menjadi menjadi pandangan hidup keagamaan setiap santri, agar mereka terbebas dari segala bentuk perbudakan dan dapat terbentuk jiwa besar yang mandiri, namun tetap tawakkal dan tawadlu'.

Secara logika, jika aqidah sudah kuat maka akan melahirkan keimanan, dan jika keimanan sudah kuat maka akan melahirkan ibadah. Ibadah merupakan aspek kedua setelah aqidah, ibadah terbagi menjadi dua, yaitu ibadah mahdlah atau muqayadah (formal serta terikat dengan syarat dan rukun tertentu); dan ibadah ghairu mahdlah atau muthlaqah (non formal serta teknik operasionalnya tidak terikat oleh syarat dan rukun tertentu). Ibadah mahdlah terdiri dari empat rukun selain dari syahadat dari kelima rukun Islam, yaitu shalat, puasa, zakat, dan haji. Sementara ibadah ghairu mahdlah adalah aktifitas ibadah selain ibadah mahdlah, seperti mengamalkan aktifitas ibadah sebagaimana pernah diamalkan oleh Rasulullah Muhammad, puasa sunnah maupun ibadah shalat sunnah lainnya.

Penekanan pada aspek ibadah tersebut juga tertuang dalam tiga kriteria santri, utamanya pada kriteria santri yang pertama, yaitu memperhatikan perbuatan-perbuatan fardlu 'ain.

Selanjutnya adalah aspek akhlak. Aspek ini lebih ditujukan kepada pembentukan kepribadian dan perilaku santri agar sesuai dengan ethical values dalam al-Qur'an dan hadits. Pada dasarnya akhlak ada dua macam, yaitu budi pekerti dan tata krama.

\section{Kesadaran Berilmu (الوعي العلمي)}

IImu secara definitif berarti mengetahui yang tidak diketahui (Idrakul Majhul), sesuatu yang belum diketahui. Sebagai makhluk yang dianugrahi akal-fikiran oleh Allah, manusia berkewajiban mencari ilmu sebagai bekal dirinya dalam meniti jalan kehidupan. Tanpa ilmu, niscaya manusia akan begitu banyak kesulitan-kesulitan dalam menempuh jalan hidupnya. Oleh sebab itu, Nabi Muhammad bersabda: "carilah ilmu sejak dari ayunan orang tua hingga masuk liang lahat" dan "carilah ilmu hingga ke negeri china."

IImu pengetahuan terbagi menjadi dua, yaitu ilmu pengetahuan agama dan ilmu pengetahuan duniawi. Para santri diharapkan menguasai kedua ilmu tersebut. Lebih jauh, kesadaran ilmu pengetahuan duniawi harus diintegrasikan dengan kesadaran ilmu pengetahuan agama. Atau 
istilah populernya adalah integrasi antara ilmu pengetahuan dan teknologi (Iptek) dengan iman dan taqwa (Imtaq). Dengan demikian, nantinya di harapakan para santri bisa menjadi ilmuwan yang muslim atau muslim yang ilmuwan.

Namun demikian, jika para santri tidak mampu menguasi kedua ilmu tersebut secara maksimal dan mengintegrasikannya, diharapkan adanya kerjasama antara santri yang menguasai ilmu agama dengan santri yang ahli dalam ilmu pengetahuan dan teknologi. Kerjasama ini di tunjukan demi terbentuknya sebuah dialektika yang bisa mengisi kekurangan masing-masing santri melalaui kelebihan yang ada pada diri mereka masing-masing, sehingga akan menciptakan sebuah perpaduan yang baik. Lebih jauh, dengan adanya keja sama itu, santri di harapkan dapat memberikan yang terbaik bagi pembangunan bangsa dan negara indonesia untuk meraih cita-cita negara yang sejahtera dan di anugrahi oleh Tuhan.

Pendapat di atas bardasarkan beberapa alasan; Pertama, firman Allah SWT. dalam surat Al-Mujadalah ayat 11, yaitu Allah meninggikan orang-orang yang beriman dan diantara kamu dan (juga meninggikan) orang-orang yang di beri ilmu pemgetahuan (bersama firman-Nya) dalam beberapa derajat.

Kedua, kisah tentang Abu Ubaidah Bin Jarrah. Waktu itu Umar Bin alKhattab RA, khalifah kedua setelah Abu Bakar as-Shiddiq RA, sangat mengagumi Abu Ubaidah. la adalah orang yang luas ilmu pengetahuannya dalam bidang duniawi, seperti ilmu sosiologi (kemasyarakatan), ilmu perekonomian, ketatanegaran, dan pertahanan. Lebih dari itu, Abu Ubaidah di kenal di kalangan sahabat orang yang mempunyai kepribadian yang luhur dan sangat jujur dalam memegang amanah (tanggung jawab). Oleh karena itu ia terkenal dengan gelar "Aminul Ummah". Gelar tersebut ia peroleh dari Nabi Muhammad SAW. Waktu itu nabi bersabda: "sesungguhnya setiap ummat mempunyai orang yang di percaya dan orang yang di percaya bagi ummat ini adalah Abu Ubaidah bin Jarrah".

Ketiga, kenyataan dunia modern sekarang ini bukan lagi tergantung kepada kesuburan tanah dan banyaknya tambang-tambang, tetapi tergantung kepada kemampuan berfikir penduduknya. Bertolak dari kenyataan dunia modern tersebut (mengenai hubungan ilmu dan agama) antara keduanya terdapat hubungan yang erat dan kuat. 
Dari sini, dapat diketahui bahwa kesadaran pertama (beragama) dari panca kesadaran di atas amat erat hubungannya dengan kesadaran yang kedua (berilmu) sebab jika salah satu diantara keduanya ditinggalkan, niscaya manusia akan mengalami ketidakseimbangan dalam menapaki alur kehidupannya. Pernyataan ini bertolak dari sabda Nabi Muhammad SAW: "barang siapa yang bertambah ilmunya tapi tidak (belum) bertambah hidayahnya, maka orang itu tidak akan bertambah(hidayah) oleh Allah, kecuali dia akan semakin jauh."

Disisi lain, kesadaran berilmu tersebut amat erat kaitannya dengan akhlak budi pekerti dan adab tatak rama (moralitas). Sebab, jika manusia mengabaikan kedua hal itu, maka ilmu yang diperoleh manusia akan siasia belaka atau tidak bermanfaat.

Pengabaian terhadap moral tersebut akan mengakibatkan hati menjadi kotor dan dipenuhi sifat-sifat maksiat. Sementara itu, ilmu adalah cahaya dan cahaya itu akan enggan masuk pada hati yang penuh dengan sifat-sifat kotor dan tidak mulia. Mengenai keengganan ilmu masuk dalam hati manusia yang terdapat sifat-sifat kotor tersebut, berikut sebuah kisah tentang imam mawardi, seorang tokoh besar dalam dunia islam yang dicela oleh gurunya, Abu Hamid Muhammad ibnu Muhammad al-Ghozali (Imam Ghozali), karena hatinya yang tidak ikhlas melaksanakan pekerjaan dari gurunya.

Saat itu, Imam Mawardi pernah merasa kesal terhadap gurunya, Imam Ghozali, karena tidak mendapatkan pelajaran ilmu dari beliau. Padahal ia telah satu tahun lebih dipondokan Imam Ghozali. Selama rentang waktu tersebut ia hanya mendapatkan pekerjaan membersihkan kotoran yang berada dibawah seal-sela terompah gurunya. Pekerjaan itu, ia lakukan setiap pagi hari setelah imam ghozli memberikan pengajaran terhadap murid-muridnya.

Nah, karena tidak sabar menerima perlakuan tersebut, Imam Mawardi, bertanya kepada gurunya soal ilmu yang tidak pernah diajarkan kepadanya. mendengar pertanyaan tersebut Imam Ghozali menjawab, "bagaimana saya dapat mengajar ilmu padamu jika dalam hatimu masih merasa jijik tatkala kau kusuruh untuk membersihkankotoran dalam terompahku?" mendengar jawaban tersebut Imam Mawardi tercengang. la sadar bahwa hatinya tidak ikhlas, hatinya masih terselimuti rasa iri terhadap sahaabt-sahabatnya yang terlebih dahulu mendapatkan dari Imam Ghozali, sementara ia tidak. Lebih-lebih, ia sadar bahwa hatinya 
meras jijik ketika membersihkan kotoran dibawah sela-sela terompah gurunya. Namun kemudian, iapun sadar bahwa keadaan hati tersebutlah yang menyebabkan keengganan Imam Ghozali memberikan ilmu padanya. Ilmu tersebut akan percuma jika diberikan padanya, sementara hatinya masih kotor.

3. Kesadaran Bermasyarakat (الوعي الإجتماعي)

Ibnu Khaldun, Penulis Kitab al-muqoddimah, pernah mengatakan: "Kehidupan bermasyarakat merupakan kebutuhan pokok bagi umat manusia". Ucapan sosiolog besar dalam dunia pemikiran Islam tersebut merupakan karakter dasar manusia. Sebab, manusia pada dasarnya tidak bisa hidup individual dalam memenuhi kebutuhan hidupnya. Manusia akan selalu membutuhkan bantuan manusialainnya, dan begitu juga sebaliknya. Kenyataan manusia tersebut, sebenarnya tidak lepas dari ketentuan Allah SWT, bahwa manusia merupakan mahkluk yang tidak sempurna. Dalam diri manusia terdapat kelebihan begitu pula kekurangan. Manusia juga sering melakukan kesalahan dan lupa.

Bertolak dari konsep manusia, menurut Ibnu Khaldun konsep kesadaran bermasyarakat ini mendapatkan pijakan filosofisnya. KH. Zaini Mun'im mengambil refrensi Ibnu Khaldun sebagai salah satu rujukan dalam perumusan konsep keempat ini, tampaknya sesuai dengan pemahaman beliau terhadap kitab suci Al-Qur'an, tepatnya surah alMaidah ayat 3: "Tolong-menolonglah atas dasar kebaikan dan taqwa, dan janganlah tolong-menolong atas dasar dosa dan permusuhan".

Melalui kesadaran bermasyarakat ini, diharapakan bahwa pesantren dan santri tidak boleh menjadi menara gading yang jauh dari masyrakatnya. Pesantren dan santri harus menyatu dalam masyarakat, artinya pesantren merupakan bagian dari masyarakat. Dengan demikian masyarakat merasa memiliki pesantren dan pesantren sebaliknya. Sehingga tidak ada kesenjangan antara pesantren beserta santri-santrinya dengan masyarakat.

Jika para santri dan pesantren serta masyarakat merasa saling memiliki, maka segala bentuk kegiatan pesantren akan memperoleh dukungan dari segenap masyarakat. Bukankah pesantren lahir di tengahtengah masyarakat untuk melakukan transformasi dan emansipasi, agar masyarakat dapat maju, baik peradabannya maupun tingkat sosialekonominya.

4. Kesadaran Berbangsa dan Bernegara (الوعي الحكومي والشعبي) 
Landasan filosofis yang mendasari KH. Zaini Mun'im merumuskan konsep keempat dari panca kesadaran santri ini, khususnya pada kesadaran berbangsanya adalah firman Allah SWT: "Sesungguhnya kami mencipkan kamu semua dari jenis laki-laki dan perempuan. Dan kami juga menciptakan kamu semua dari suku-suku bangsa agar saling mengenal". Sementara sabda Nabi Muhammad SAW tentang cinta terhadap tanah air adalah termasuk bukti keimanan, juga merupakan dasar untuk merumuskan konsep kesadaran ketiga ini, khususnya kesadaran bernegaranya.

Daari dalil di atas, maka terbentuklah satu kesatuan konsep, yaitu kesadaran berbangsa dan bernegara. Konsep ketiga ini tidak bisa dipisah atau di balik. Karena, pertama, kesadaran berbangsa amat erat kaitannya dengan kesadaran bernegara. Artinya, berdirinya sebuah negara tidak akan pernah di akui oleh negara lainnya apabila di dalam negara tersebut tidak ada bangsa atau rakyatnya. Dan meskipun rakyatnya ada, tapi jika mereka tidak mengakui keberadaan negara, maka keberadaan negara tersebut akan terasa hambar.

Kedua, kesadaran bernegara juga amat amat erat kaitannya dengan kesadaran berbangsa. Artinya sebuah bangsa akan cendrung tidak tertib, tidak aman dan tidak sejahtera apabila tidak ada sebuah negara yang bertanggung jawabmelindungi dan mengupayakan terpenuhinya kebutuhan bangsanya. Negara dalam konteks ini merupakan institusi atau lembaga yang bertanggung jawab atas kesejahteraan rakyatnya baik dalam bidang politik, ekonomi, sosial, budaya, hukum, pendidikan, pertahanan, dan keamanan. Jika tidak ada negara, tak terbayangkan, apakah bangsa atau rakyat bisa memenuhi beberapa kebutuhannya tersebut. Sebab itu integrasi antara keduanya amat penting.

Ketiga, konsep kesadaran berbangsa dan bernegara ini tidak bisa di balik. Sebab jika kesadaran bernegara didahulukan daripada kesadaran berbangsa maka hal ini akan tamapak ironi sekali. Negara tidak akan pernah ada tanpa keberdaan bangsa terlebih dahulu. Karena keberadaan adalah hasil karya dan cipta sebuah bangsa. Dengan pengertian demikian, dapat di ketahui bahwa kesadaran berbangsa mendahului daripada kesadaran bernegara. Lebih jauh, dengan mengedepankan kesadaran berbangsa, maka kedaulatan negara adalah di tangan bangsa atau rakyat. Dan hal ini sesuai bentuk negara Indonesia, yaitu demokrasi; dari rakyat, oleh rakyat dan untuk rakyat. 
Selain dari al-Qur'an dan Al-Hadist di Atas, dalam merumuskan konsep kesadaran keempat ini, Kiai Zaini juga tarinspirasi oleh pengalaman perjuangan beliau bersama-sama ulama dan rakyat Indonesia ketika merebut kemerdekaan. Hal ini terbukti dengan aktifnya beliau dalam beberpa oraganisasi seperti Nahdlatul Ulama (NU) dan organisasi Radddah di pamekasan, bergabung dengan TAB/RESIMEN, Pembela tanah air (Peta), Front Pertahanan Rakyat dan barisan Sabilillah mulai tahun 1945-1947, dan terakhir menjadi Rais Syuriah Wilayah Jawa Timur sejak tahun 1952 s/d 1972 serta pernah menjadi dewan pertimbangan dalam tubuh organisai NU.

Perjuangan tersebut, tampaknya begitu begitu lekat dalam benak Kiai Zaini. Hingga kemudian semangat berjuangan itu ingin beliau turunkan kepada seluruh santri-santrinya. Harapan tersebut, tampak dari jawaban beliau ketika Jendral Basuki Rahmat, Kepala Staf angkatan Darat(KSAD) tahun 1968, bekunjung kepada beliau dan mengajukan pertanyaan: "dengan mendirikan pesantren ini apakah anda akan mencetak kiai atau intelektual muslim?" Dengan tenang KH. Zaini menjawab: "Tidak keduaduanya. Saya mendirkan PP. Nurul Jadid initidak untuk mencetak kiai atau intelektual muslim. Tapi sederhana saja, saya akan mencetak muslimmuslim yang aktif berjuang di masyarakat dengan bakat dan keahliannya masing-masing. Jika di antara santri saya ada yang ahli dalam bidang pendidikan, ya silahkan. Jika ada dalam bidang ekonomi, ya silahkan. Sebab sahabat-sahabat rasulullah itu semuanya merupakan muslimmuslim yang aktif berjuang. Dan saya amat tidak senang apabila ada di antara santri saya yang menjadi tokoh besar (Kiai atau Intelektual Islam) tapi mereka pasif dalam berjuang. Saya akan lebih senang apabila melihat alumni santri Nurul Jadid yang menjadi kondektur bus, tapi ia aktif berdakwah amar makruf nahi mungkar".

Demikianlah, dengan kesadran berbangsa dan bernegara tersebut, santri-santri Nurul Jadid diharapkan memiliki semangat juang yang tinggi dan menjadi muslim yang aktif. Sehingga mereka akan merasa memiliki dan bertanggung jawab terhadap maju-mundurnya bangsa dan Negara Republik Indonesia ini.

5. Kesadaran Berorganisasi (الوعي النظامي)

Adanya sebuah organisasi yang aktif, efektif dan efesien adalah mutlak diperlukan bagi setiap santri dan pesantren. Sebab titik lemah Islam dan pesantren adalah oraganisasinya. Kelemahan dalam 
organisasinya menunjukkan kelemehan pada sumber daya manusia (SDM). Ali bin Abi Thalib telah mengingatkan, "kebenaran yang tidak terorganisir dengan baik akan di kalahkan dengan kebatilan yang terorganisir".

Kesadaran berorganisasi ini di rumuskan tidak lain karena selama ini umat Islam hanya dengan jumlahnya yang mayoritas. Mereka tidak pernah melihat kelemahannya dalam bersaing dengan saudara yang lain, yang dipandang minoritas, baik dalam perbaikan pendidikan, peningkatan ekonomi maupun peranannya dalam politik. Padahal Allah SWT telah mengingatkan, "betapa banyak golongan minoritas mengalahkan golongan mayoritas dengan izin Allah"

Sebab itulah, santri Nurul Jadid harus mampu aktif dalam organisasi. Karena melalui media ini semua tujuan bersama akan lebih mudah diraih dengan maksiamal. Organisasi adalah pola hubungan yang saling saling terkait antar satu bagian dengan bagian yang lainnya, yang lebih mengedepankan komuikasi dan koordinasi dalam menjalankan aktifitasnya sehinngga dapat mencapai tujuan bersama.

Kesadaran berorganisasi ini dirumuskan, selain karena rasa prihatin Kiai Zaini terhadap eksistensi umat Islam, juga berangkat dari pengalaman beliau semasa di Jam'iyyah Nahdlatul Ulama (NU) sejak tahun 1952 hingga tahun 1972. Dalam organisasinya melalui pemikiran dan gagasan cemerlangnya, beliau juga selalalu konsisten memegang etika dan moralitas dalam berorganisasi.

\section{Servant Leadership Dalam Implementasi Nilai-nilai Trilogi dan Panca Kesadaran Santri}

Trilogi dan panca kesadaran santri merupakan pilar utama yang perlu ditanamkan pada setiap santri Pondok Pesantren Nurul Jadid, namun hal itu tidak mudah dilakukan. Sebab santri yang menetap di pondok pesantren bersifat heterogen, mereka terdiri dari beberapa unsur yang memiliki karakteristik yang berbeda mulai dari daerah, adat, tradisi dan kebiasaan. Selain itu latar belakang keluarganya juga sangat variatif, ada yang kaya ada yang berkecukupan, ada yang dari keturunan orang terhormat atau tokoh dan ada yang keturunan orang biasa, termasuk profesi masing-masing wali atau orang tua. Oleh karena itu pola kepemimpinan pelayan atau servant leadership yang 14 abad tahun lalu diajarkan Rasulullah dan dipekenalkan 178 
EVALUASI, 3(2), September 2019, ISSN 2580-3387 (print) |

ISSN 2615-2886 (online)

http://doi.org/10.32478/evaluasi.v3i2.251

kembali oleh Greenleafini sudah diimplementasikan oleh jajaran pengurus Pondok Pesantren Nurul Jadid dalam penerapan nilai-nilai trilogi dan panca kesadaran santri.

Pada hakikatnya, Jauh sebelum Greanleaf memperkenalkan teorinya, hampir seluruh pondok-pondok pesantren yang tersebar luas di Indonesia sudah menerapkan pola kepemimpinan pelayan atau Servant Leadership secara kultural-alamiah, walaupun juga ada pesantren yang menerapkan pola kepemimpinan lainnya.

Salah satunya adalah Pondok Pesantren Nurul Jadid yang terletak di Pulau Jawa belahan timur tepatnya di kabupaten Probolinggo. Sejak dari awal berdiri, Nurul Jadid sudah menerapkan kepemimpinan pelayan kepada seluruh santri, hal ini dalam rangka memberikan pelayanan terbaik kepada santri untuk tercapainya pemahaman dan penanaman nilai-nilai tentang trilogi santri dan panca kesadaran santri.

Santri sebagai titipan orang tua selayaknya terlayani dengan baik, sehingga sesuatu yang menjadi kebutuhan dan tujuan santri mondok bisa tercapai. Setiap santri mempunyai tujuan yang berbeda-beda, namun pada umumnya pesantren sendiri juga mempunyai tujuan mendasar yang berorientasi pada ilmu agama (aqidah, akhlaq, dan fiqih) dan ilmu umum termasuk sosial-kemasyarakatan, begitu pula dengan Pondok Pesantren Nurul Jadid. Dalam mencapai tujuan bersama antara santri dan pondok pesantren maka dilakukan integrasi dan sinergitas antara pesantren dengan lembaga pendidikan formal yang ada dibawah naungan pesantren dengan tetap menjadikan trilogi dan panca kesadaran santri sebagai pondasi utama.

Nurul jadid sendiri pada praktiknya dalam penerapan nilai-nilai trilogi dan panca kesadaran santri menitikberatkan kepada pengurus wilayah atau pengurus asrama sebagai orang pertama yang bersentuhan langsung dengan santri dalam setiap aktifitas sehari-hari. Pengurus harus benar-benar paham akan kondisi masing-masing setiap individu santri, mulai dari latar belakang keluarga, kepribadian, kebiasaan, karakter, sampai hal-hal yang sifatnya privasi, itu semua bertujuan untuk memudahkan dalam kontrol-pengawasan dan pelayanan terhadap santri.

Kaitannya dalam penerapan servant leadership Pondok Pesantren Nurul jadid membentuk pola khusus, yaitu sistem kewaliasuhan. Dimana setiap 
pengurus harus menjadi wali asuh dari 10 sampai 15 santri dari setiap asrama. Wali asuh secara umum bertanggungjawab penuh terhadap santri yang menjadi anak asuhnya, seperti yang telah dikemukakan di atas, wali asuh harus paham akan kondisi individu santri. Namun tidak hanya paham begitu saja, wali asuh harus bertanggungjawab terhadap apa yang menjadi kebutuhan santri yang menjadi anak asuh, mulai dari hal terkecil sampai yang besar seperti makan, minum, komunikasi dengan orang tua, masalah pribadi sampai urusan masa depan seperti pendidikan lanjutan dan cita-cita. Dari itu semua secara tidak langsung nilai-nilai trilogi dan panca kesadaran santri sudah diterapkan dan diajarkan kepada anak asuh.

Selain itu pengurus yang menjadi walih asuh juga harus memenuhi kebutuhan santri terkait nilai-nilai kesantrian dan menjadi pembina dalam rangka memberi pemahaman dasar kepada santri tentangfurudlul 'ainiyah sesuai yang tertuang dalam trilogi santri. Setiap wali asuh diberi buku penghubung dengan anak asuh dalam memonitoring perkembangan santri sejak dari pertama mondok sehingga data bisa terukur. Tidak cukup itu, pengurus yang menjadi wali asuh juga harus memberikan tauladan sebagai bentuk pengajaran kepada santri dalam hal apapun yang diharuskan oleh pesantren seperti shalat berjamaah, mengaji, belajar, dan pendampingan dalam setiap kegiatan, karena pengurus harus merasakan apa yang dirasakan oleh santri sebagai rasa bentuk empati.

Begitu pula dalam penanaman nilai-nalai panca kesadaran santri, pengurus daerah mengajarkan kepada santri dengan menjadikannya sebagai pengurus harian daerah, dan dalam setiap daerah yang terdiri dari beberapa kamar diharuskan membentuk struktur pengurus kamar, dalam setiap kamar terdiri dari unsur santri yang berbeda daerah asal dan kebudayaan, hal ini bertujuanuntuk memberikan peran kepada santri sebagai latihan membentuk kepribadian dan kepekaan yang didasarkan kepada panca kesadaran santri.

Selain memberikan peran, pengurus dan wali asuh juga memberikan waktu bersama santri dengan melakukan pendekatan persuasif dan memberikan stimulus sehingga apa yang menjadi keluhan dan problem dalam diri santri baik yang sifatnya privasi maupun yang sifatnya umum, serta memberikan solusi dengan tepat dan bijak. Karena pada dasarnya santri sebagai manusia memiliki naluri untuk mengungkapkan hal-hal tentamg 
EVALUASI, 3(2), September 2019, ISSN 2580-3387 (print) |

ISSN 2615-2886 (online)

http://doi.org/10.32478/evaluasi.v3i2.251

dirinya.Tidak cukup begitu saja, dalam melakukan pendekatan pengurus atau wali asuh memberikan doktrin tentang urgensitas trilogi dan panca kesadaran santri sebagai bekal utama dalam hidup bermasyarakat.

\section{KESIMPULAN}

Berdasarkan uraian di atas servant leadership sudah diterapkan oleh pengurus Pondok Pesantren Nurul Jadid dimana pola kepemimpinan ini sangat membantu kepada tercapainyan pemahaman dan penanaman nilainilai kesantrian yang termaktub dalam trilogi dan panca kesadaran santri. Dalam penerapannya Pondok Pensantren Nurul Jadid membentuk pola kewaliasuhan dari unsur pengurus wilayah dan pesantren dengan ketentuan satu pengurus menjadi wali asuh dari 10 sampai dengan 15 santri.

Pengurus yang memiliki peran sebagai wali asuh menanamkan nilainilai trilogi dan panca kesadaran santri dengan pembiasaan, ketauladanan, kontrol-pengawasan, dan pemberian peran guna menumbuhkan rasa empati antara wali asuh dan santri sebagai anak asuh. Setiap pengurus secara umum harus melakukan pendekatan persuasif, karena selain menjadi pembina, pengurus juga memiliki peran pengganti dari orang tua. Oleh karena itu dengan pendekatan maka santri atau anak asuh akan terbuka dan menyampaikan keluhan dan masalah pribadi, sebagai seorang manusia santri atau anak asuh perlu didengar dan diperhatikan.

Selain membangun jiwa kewaliasuhan dengan rasa empati, pengurus juga memiliki tanggungjawab untuk menjadi konselor dengan peran memberikan motivasi, solusi, dan menjadi teman curhat untuk perkembangan pribadi santri dalam implementasi nilai-nilai trilogi dan panca kesadaran santri.

\section{DAFTAR PUSTAKA}

Baharun, Hasan, 'Peningkatan Kompetensi Guru Melalui Sistem Kepemimpinan Kepala Madrasah', 6 (2017), 1-26

Barbuto, John E., and Daniel W. Wheeler, 'Scale Development and Construct Clarification of Servant Leadership', Group and Organization Management, 31 (2006), 300-326

Fahmi, Ilham, 'Pengaruh Kepribadian Dan Persepsi Kerja Guru Terhadap Organizational Citizenship Behavior (Ocb) Guru Sma Negeri SeKabupaten Karawang', 1 (2017), 112-21 
EVALUASI, 3(2), September 2019, ISSN 2580-3387 (print) |

ISSN 2615-2886 (online)

http://doi.org/10.32478/evaluasi.v3i2.251

Hasan Baharun, 'Manajemen Kinerja Jurnal I Lmu Tarbiyah " At - Tajdid ", Vol . 5 No . 2 , Juli 2016', Jurnal I Lmu Tarbiyah " At - Tajdid, 5 (2016), 24362

Ibrahim, Izani Bin, and Dr. Yahya Bin Don, 'Servant Leadership and Effective

Changes Management in Schools', International Journal of Scientific and

Research Publication, 4 (2014), 1-8

Ila Kholilah, 'AN-NIDHOM (Jurnal Manajemen Pendidikan Islam) URGENSI

KEPEMIMPINAN DALAM ISLAM Ila Kholilah', 1, 117-30

Kadarusman, Dadang, 'Natural Intellegence Leadership: Cara Pandang Baru

Terhadap Kecerdasan Dan Karakter Kepemimpinan', in Jakarta: Raih

Asa Sukse, 2012, p. 23

Muizu, Wa Ode Zusnita, 'Pengaruh Kepemimpinan Terhadap Kinerja

Karyawan', Jurnal Pekbis, 6 (2014), 1-13

Rais Hidayat, 'Perilaku Etis Dosen Dalam Persfektif Efikasi Diri,

Kepemimpinan, Dan Komunikasi Interpersonal', 1 (2017), 37-44

Russell, Robert F., and A. Gregory Stone, 'A Review of the Servent Leadership

Attributes', Leadership \& Organization Development Journal, 23/3

(2002), 145-57

Tatilu, James, Victor P.K Lengkong, and Greis M. Sendow, 'Kepemimpinan

Transaksional, Transformasional, Servant Leadership Pengaruhnya

Terhadap Prestasi Pekerja Pada PT. Sinar Galeson Pratama Manado',

Emba, 2 (2014), 295-304

Wahab, Abdul Aziz, 'Anatomi Organisasi Dan Kepemimpinan Pendidikan', in

Bandung: Alfabeta, 201AD, p. 34

Wahyuni, Dewi Urip, Budiman Christiananta, and Anis Eliyana, 'Influence of

Organizational Commitment, Transactional Leadership, and Servant

Leadership to the Work Motivation, Work Satisfaction and Work

Performance of Teachers at Private Senior High Schools in Surabaya',

Educational Research International, 3 (2014), 82-96

Yahya, Izani \&, 'Kepimpinan Servant Dan Pengaruhnya Terhadap Pengurusan

Perubahan Di Sekolah', Jurnal Pendidikan Malaysia, 39 (2014), 19-26 